\author{
Marin Bachvarov \\ Katedra Geografii Miast i Turyzmu \\ Uniwersytetu Łódzkiego \\ ul. Kopcińskiego 31 \\ 90-142 Łódź \\ bachvar@geo.uni.lodz.pl
}

\section{Walory turystyczne (Turistićeski resursy), Naiden Apostolow, Wyd. Uniwersytetu Ekonomicznego w Warnie, 2003, 387 ss.}

Bułgarska geografia turyzmu, która w latach 70 . i 80. XX w. należała do bardziej zaawansowanych (patrz artykuł S. Liszewskiego: „Turyzm”, z. 2, 1986, s. 5-23), ostatnio ponownie się uaktywniła. Przykładem tego jest opublikowanie kilku interesujących monografii i podręczników, nie mówiąc o serii artykułów naukowych, drukowanych przeważnie w wydawnictwach uniwersytetu sofijskiego, gdzie funkcjonuje Katedra Turystyki przy Wydziale Geologiczno-Geograficznym i Zakład Marketingu Turystycznego na Wydziale Ekonomicznym. Również w Warnie, która jest pierwszym ośrodkiem dydaktyki i badań nad turystyką powstałym jeszcze w latach 60. XX w., uaktywnili się geografowie turyzmu.

Warto tu zwrócić uwagę na kilka pozycji książkowych, które ukazały się po roku 1999. Przede wszystkim należy wymienić monografię Wasila Marinowa i zespołu pt. Monitoring popytu turystycznego, zrealizowaną $\mathrm{z}$ pomocą British Council na podstawie badań gminy Bansko (Wyd. Uniwersytetu w Sofii, 1999), monografię Marii Wodenskiej, zatytułowaną Wplywy gospodarcze, spoteczne i przyrodnicze turystyki (Wyd. Uniwersytetu w Sofii, 2001), książkę Enczo Kostowa Turystyka kulturowa (Wyd. Uniwersytetu Gospodarki Światowej w Sofii), jak i wydaną w roku 2000 w Warnie pracę pt. Hotelarstwo w Europie kategorie, lokalizacje, rozwój, autorstwa Tani Dybewej, Naidena Apostołowa i Georginy Łukanowej.

\section{Tourism Resources (Turisticeski resursy) by Naiden Apostolow, published by the University of Economics in Varna, 2003, 387 pp.}

Bulgarian tourism geography, among the most advanced in the 1970s and 80s (see article by Liszewski in "Turyzm", vol. 2, 1986, pp. 2-23), seems to be reviving. Several interesting monographs and textbooks have been published, not to mention a number of academic articles, mostly published by the Tourism Dept of the Geology and Geography Faculty at Sofia University, as well as the Tourism Marketing Dept at the of Economics Faculty. In Varna too, the first centre of tourism education and research set up in the 1960s, tourism geographers have become active again.

Several books which have appeared since 1999 are worth looking at and above all a monograph by Vasil Marinov and his team, entitled Monitoring Tourism Demand, (published with the help of the British Council) and based on research into the gmina of Bansko (published by Sofia University, 1999), a monograph by Maria Wodenska, entitled Economic, Social and Natural Influences on Tourism (published by Sofia University, 2001), as well as Cultural Tourism a book by Enczo Kostov (published by the University of the Global Economy in Sofia), and The Hotel Industry in Europe: categories, locations, development by Tania Dybewa, Naiden Apostolov and Georgina Lukanova (published in Varna in 2000). 
Najnowszą i wartościowa pozycją z dziedziny turystyki jest publikacja Walory turystyczne (bułg. Turistićeski resursy), pióra doc. dr. Naidena Apostołowa, wieloletniego wykładowcy z Uniwersytetu Ekonomicznego w Warnie.

W książce przedstawiono monograficzne i kompleksowe badanie walorów turystycznych jako podstawowego przedmiotu geografii turyzmu.

Część pierwsza omawianej publikacji, zatytułowana: „Teoretyczne aspekty badań walorów turystycznych”, zawiera rozdziały: I. „Istota, zadania i znaczenie wiedzy turystyczno-geograficznej i walorów turystycznych”, II. „Rozwój i osiągnięcia w badaniach walorów turystycznych”, III. „Klasyfikacja walorów turystycznych".

Część druga, pt. „Walory przyrodniczo-turystyczne”, obejmuje rozdziały: IV. „Cechy walorów przyrodniczo-turystycznych”, V. „Rzeźba”, VI. „Klimat”, VII. „Wody”, VIII. „Roślinność i świat zwierzęcy".

Część trzecia dotyczy walorów antropogenicznych, a poszczególne rozdziały to: IX. „Cechy walorów antropogenicznych”, X. „Walory historyczno-archeologiczne”, XI. „Walory architektoniczno-etnograficzne i pielgrzymkowe”, XII. „Parki rozrywkowe”, XIII. „Walory biznesowe, kulturowe i sportowe".

Część czwarta poświęcona jest analizie ochrony walorów turystycznych, zawartej w dwóch rozdziałach: XIV. „Negatywne wpływy na walory turystyczne” i XV. „Ochrona walorów turystycznych".

Część piąta przedstawia terytoria i regiony turystyczne w rozdziałach: XVI. „Istota, rozwój i klasyfikacja terytoriów turystycznych” i XVII. „Regiony turystyczne".

Jak wynika z przeglądu spisu treści, plan opracowania jest tradycyjny, lecz w poszczególnych rozdziałach dominują wartościowe i głębokie analizy, konfrontuje się różne stanowiska i podejmuje dyskusję, proponowane są innowacyjne rozwiązania. Zatem powstała praca wszechstronna, rzetelna, uwzględniająca dużą część dorobku naukowego w dziedzinie geografii turystycznej. W pracy nie ma modnych ostatnio studiów przypadków, ale nie stanowi to niedostatku. Biorąc pod uwagę bardzo szeroki temat, nie byłoby możliwe zilustrowanie wszystkich elementów walorów turystycznych na konkretnych przykładach studiów przypadków. Myślę, że sprawdza się tu podejście dedukcyjne od przyjętej z góry syntezy (uzasadnionej wieloma pozycjami w literaturze naukowej) do analizy poszczególnych elementów i aspektów.
The most recent book on tourism is Tourism Resources (Bulg. Turisticeski resursy) by Dr Naiden Apostolov, a longstanding lecturer at the University of Economics in Varna. His book presents a monographic and comprehensive study of tourism resources as a basic theme of the geography of tourism. It consists of a preface and five parts.

Part I - "Theoretical Aspects of Studying Tourism Resources" contains the following chapters: I - "The Basis, Objectives and Significance of Tourism Geography and Tourism Resources", II - "Development and Achievements in the Study of Tourism Resources", III - "Classification of Tourism Resources".

Part II - "Natural Resources" includes: IV - "Features of Natural Resources", V "Landscape", VI - "Climate", VII - "Water resources", VIII - "Flora and Fauna".

Part III - considers anthropogenic resources and is divided into: IX "Features of Anthropogenic Resources", X "Historical and Archaeological Resources", XI - "Architectural, Ethnographic and Pilgrimage Resources", XII - "Amusement Parks", XIII - "Business, Cultural and Sports Resources".

Part IV - is devoted to the analysis of tourism resource protection: XIV - "Negative influences on Tourism Resources" and XV "Tourism Resource Protection".

Part V - presents tourism areas and regions: XVI - "The Basis, Development and Classification of Tourism Areas" and XVII "Tourism Regions".

As seen from the contents, the structure of the book is traditional but individual chapters are marked by valuable and thorough analyses, different approaches are set against one another, while discussion and innovative solutions are suggested. The book is based on the solid ground of academic achievement in the geography of tourism. Although it does not include the case studies so fashionable recently, this is not a drawback. Considering the very wide range of the theme it would have been impossible to illustrate all elements of tourism resources through particular examples. I think the didactic approach proves effective here - moving from general 
Praca Apostołowa jest oparta na bardzo szerokim rozeznaniu $w$ światowej literaturze naukowej. W spisie podano 321 źródeł bibliograficznych cytowanych najczęściej wielokrotnie $w$ tekście. Należy zaznaczyć, że Autor korzysta z wielu polskich publikacji - od prac S. Leszczyckiego z lat 30. do Geografii turyzmu A. Kowalczyka $\mathrm{z}$ roku 2000.

Treść ilustracji nie budzi na ogół wątpliwości, gorzej z ich jakością. Stosunkowo słabiej przedstawiono nowsze pozycje $z$ literatury anglojęzycznej. $\mathrm{Za}$ to bardzo dobre jest rozeznanie literatury naukowej krajów Środkowo- i Wschodnio-Europejskich.

Pomijając to, że w literaturze naukowej jest niewiele monografii poświęconych kompleksowemu ujęciu walorów turystycznych, główną zaletą recenzowanej pozycji jest wszechstronna analiza niemal wszystkich istotnych aspektów naukowych i aplikacyjnych związanych $\mathrm{z}$ szeroko pojętymi walorami turystycznymi. Poziom naukowy, tradycyjne, a zarazem innowacyjne myślenie sprawia, że Czytelnik odbiera pracę Apostołowa jako wydarzenie $w$ geografii turystycznej. Świadczy to o tym, iż w nauce małe wspólnoty językowe nie są z góry na straconej pozycji, pod warunkiem że nastapi promocja ich dorobku na arenie międzynarodowej.

Szczególnie interesujący i mający moim zdaniem szersze znaczenie jest rozdział II. „Rozwój i osiągnięcia badań nad walorami turystycznymi”, gdyż stanowi spójną wizję dotychczasowego rozwoju całej geografii turyzmu, z wytyczeniem jej zadań na przyszłość.

W książce są drobne potknięcia stylistyczne i nieścisłości, a jakość poligraficzna wydawnictwa nie jest najwyższa.

Co do meritum opracowania, mam jedna, za to poważna, uwagę krytyczną - brakuje w pracy opisu mechanizmu powstania produktu turystycznego - od sprzyjających warunków otoczenia, przez potencjalne walory turystyczne, przez proces powstania walorów (za pomocą nakładów pracy i środków) do zaistnienia na rynku turystycznym, jako określony i rozpoznawalny produkt ze swoimi parametrami marketingowymi (miejsce, sezon, organizacja podróży, usługi, cena, promocja). Jest to przykład, że nawet w najlepszych pracach geograficzno-turystycznych w dalszym ciagu niedoceniany jest jakże geograficzny - marketing miejsca. assumptions based on the existing literature, towards an analysis of individual elements and aspects.

Apostolov's work is based on his vast knowledge of literature throughout the world on the subject and the bibliography includes 321 references some of them cited many times in the text. It should be noted that the author refers to many Polish publications - from Leszczycki's works from the 1930s to Geografia turyzmu by Kowalczyk from 2000. The illustrations raise no doubts as to their quality. The presentation of the latest literature published in English is relatively weaker but knowledge of the literature of Central and East European countries is impressive.

Apart from the fact that there are very few monographs devoted to a comprehensive study of tourism resources, the main advantage of this book is its detailed analysis of almost all significant theoretical and applied aspects. The standard of the work, as well as the traditional yet innovative thinking, mean the reader will find Apostolov's book a revelation in the geography of tourism. It shows that minority languages stand a very good chance academically provided their achievements are promoted internationally.

Chapter II ("The Development and Achievements in the Study of Tourism Resources") is particularly interesting as it presents a coherent picture of the development of the geography of tourism until the present, and points to its future tasks. There are however some small stylistic inaccuracies and in addition the printing quality is not very high.

I have one serious reservation regarding the content which is the absence of a presentation of the mechanism of tourism product creation, starting from favourable surrounding conditions, through potential tourism resources, the process of resource creation (by the input of labour and finance), to emergence on the tourism market as a defined and recognisable product with marketing parameters (place, season, organisation of travel, services, promotion). It is an example which shows that even the authors of the best publications in tourism geography still underestimate the marketing of tourism destinations. 